\title{
IS PRECARIOUS EMPLOYMENT LOW INCOME EMPLOYMENT? THE CHANGING LABOUR MARKET IN SOUTHERN ONTARIO
}

Wayne Lewchuk

Professor,

School of Labour Studies and

Department of Economics,

McMaster University,

Hamilton, Ontario, Canada

Michelynn Laflèche

Director of Research,

Public Policy and Evaluation,

United Way Toronto,

Toronto, Ontario, Canada

Diane Dyson

Director,

Research and Public Policy, WoodGreen Community Services,

Toronto, Ontario, Canada

Luin Goldring

Associate Professor,

Department of Sociology,

York University,

Toronto, Ontario, Canada

Alan Meisner

Principal,

Quantacan,

Toronto, Ontario, Canada
Stephanie Procyk

Manager,

Research, Public Policy and Evaluation, United Way Toronto,

Toronto, Ontario, Canada

Dan Rosen

Senior Policy Advisor,

Economic Development and Culture

Division,

City of Toronto,

Toronto, Ontario, Canada

John Shields

Professor,

Department of Politics and Public

Administration,

Ryerson University,

Toronto, Ontario, Canada

Peter Viducis

Manager, Economic Research and

Business Info,

Economic Development and Culture,

City of Toronto,

Toronto, Ontario, Canada

Sam Vrankulj

Project Manager,

Poverty and Precarious Employment in

Southern Ontario,

McMaster University,

Hamilton, Ontario, Canada 


\section{ABSTRACT}

This paper examines the association between income and precarious employment, how this association is changing and how it is shaped by gender and race. It explores how precarious employment has spread to even middle income occupations and what this implies for our understanding of contemporary labour markets and employment relationship norms. The findings indicate a need to refine our views of who is in precarious employment and a need to re-evaluate the nature of the Standard Employment Relationship, which we would argue is not only becoming less prevalent, but also transitioning into something that is less secure.

\section{INTRODUCTION}

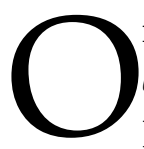
ne of the key findings of the It's More than Poverty: Precarious Employment and Household Wellbeing (PEPSO 2013) report is the extent to which precarious employment has spread to middle income earners. The likelihood of being precariously employed is still greatest for low income earners, a likelihood that falls as income increases. However, given that middle income earners represent the largest cohort of all income earners, they also represent a significant share of all those in precarious employment. This paper examines the association between income and precarious employment and how this association is shaped by gender and race.

The increasing prevalence of precarious employment in Canada has been noted in numerous recent studies (Vosko 2009; LCO 2012; TD Economics 2013; Institute for Competitiveness and Prosperity 2013). Much of the discussion of the growth in precarious employment has focused on low income earners. The combination of low income and employment uncertainty has been shown to affect physical and mental health, community relations, access to training and overall quality of life. Our research suggests that focusing only on low income earners is missing more profound labour market changes and the spread of precarious employment to a wide range of socio-economic groups. Amongst the 25 percent of workers in the most insecure employment relationships in our study, over one-third define themselves as knowledge workers, nearly one-third are in jobs that require a university degree and over one-third report annual incomes over $\$ 40,000$.

In what follows, we show that low income earners are more likely to be in precarious employment than either middle or high income earners. However, a significant number of low income earners report being in secure employment and a significant number of middle and high income earners are in precarious employment. This suggests a need to refine our views of who is in precarious employment and the nature of low income employment. It also points to a fundamental shift in Canadian labour markets and the spread of precarious employment to socio-economic groups that were immune from this form of 
employment in the past. Good paying jobs in sectors such as the media, IT, university research, health care and social services are less and less likely to be based on permanent full-time employment relationships. The association between low income and precarious employment is particularly strong for non-white racialized workers. However, the association is less evident for women or for men in precarious employment who are more evenly divided across income ranges. Our findings support that there has been a feminization of employment norms. While women continue to be paid significantly less than men, there are surprisingly small differences in the degree of employment insecurity between men and women. Nonwhite racialized workers continue to experience more employment precarity and lower income than whites (Goldring and Landolt 2011, 2009; Goldring and Joly this volume).

In the decades following World War II, women and workers from non-white racialized groups were more likely to experience both low income and insecure employment (Vosko 2000; Galabuzi 2004). The earliest temporary employment agencies focused on supplying women to fill low wage temporary positions (Hatton 2011). Studies of more recent periods suggest that the employment norms women faced in the 1950s and 1960s have been generalized to a broad segment of male and female workers. Today, temporary employment agencies supply workers to all sectors and at all income levels (Hatton 2011). This has led several authors to suggest that employment norms and conditions have been feminized (Armstrong 1996; Vosko 2000; Hebson and Grugulis 2005). The changes in Canadian labour markets that we are witnessing currently are more fundamental than men moving into service type jobs that in the past were dominated by women, or women moving into more secure occupations that used to be dominated by men. Instead, what we are observing is the transition of entire sectors such as media from secure to less secure employment. At the same time, employment is growing in several sectors where employment tends to be reasonably well paid, but short-term and insecure. Skilled knowledge workers dominate many of these sectors, as is the case in many "rich" countries.

These findings suggest a need to re-evaluate the nature of the Standard Employment Relationship, which we would argue is not only becoming less prevalent, but also transitioning into something that is less secure. They also suggest that precarity has multiple dimensions and that gender and race are associated with different components of precarity. For example, while on average men and women report similar levels of employment insecurity overall, men are less likely than women to report being in a temporary employment relationship, but more likely to report income uncertainty and uncertainty regarding their work schedules. A similar finding applies to white and non-white racialized workers. Non-white workers report more employment insecurity on average than white workers, but not on all dimensions of the employment relationship. Non-white workers are less likely to be in a Standard Employment Relationship, and more likely to report income uncertainty as a result of having less control over future 
employment and less likely to be paid when absent from work. However there are no significant differences between white and non-white workers in the probability of receiving supplemental employment benefits, or over scheduling uncertainty.

\section{THE EMPLOYMENT PRECARITY INDEX}

The PEPSO research group developed the Employment Precarity Index used to define precarious employment in this paper. It combines ten direct and indirect measures of employment insecurity using data from our 2011/12 survey conducted in the Hamilton-Greater Toronto area. The form of the employment relationship, including whether a worker is employed through a temporary employment agency or is in a permanent position, is an indirect measure of employment insecurity. While indicative of the level of employment insecurity, not all temporary employment agency work is insecure, nor is all so-called permanent employment necessarily secure. A more accurate way of measuring the level of insecurity of an employment relationship is to use direct measures including measures of income insecurity, lack of control over work schedules and insecurity associated with raising rights at work. By combining direct and indirect measures, the Index provides a comprehensive measure of overall employment precarity. Below, the ten components that make up the Employment Precarity Index are described. Each of the ten components of the Index are scored between zero and ten. The sum of these ten components provides an index with a maximum score of 100 . Higher scores represent more precarious employment relationships. ${ }^{1}$

\section{FORM OF THE EMPLOYMENT RELATIONSHIP}

Two components of the Index measure the form of the employment relationship. The first component combines three different questions from the survey to assess if the individual is in a Standard Employment Relationship (SER). To be in a SER the individual has to indicate that they have a permanent full-time job of at least 30 hours of work per week with one employer, that they expect to have this job over the next 12 months, and that the job provides some supplementary benefits beyond a basic wage. The second question is a measure of the degree of insecurity associated with eight different forms of the employment relationship. These range from employment through a temp agency which is the most temporary form of employment, to less temporary forms such as fixed term contracts to permanent full-time employment which is the least temporary form of employment.

\section{INCOME UNCERTAINTY}

Four components of the Index provide direct measures of income uncertainty which is a core characteristic of precarious employment. The first question measures the degree to which income varies from week to week. The second measures the likelihood that a worker's hours of work will be reduced in the near future. The 
third measures if workers receive benefits beyond a wage that might protect them from unexpected expenses. The final question measures if workers are paid if they miss work.

\section{SCHEDULING UNCERTAINTY}

Two different components provide direct measures of scheduling uncertainty. The first asks if the worker is an on-call worker which can mean variability in amount of work and work schedule. The second question measures if the worker knows their work schedule at least one week in advance.

\section{RELATIONSHIP UNCERTAINTY}

Relationship uncertainty captures both the degree to which employment relationships can be viewed as informal or casual relationships and the relative power of employers and workers in a relationship. It is captured by two components. Being paid in cash is often an indicator of an employment relationship that is relatively casual and informal and that often falls outside of the standard legal framework regulating employment. The second question measures whether a worker feels raising a health and safety issue or an employment rights issue might affect future employment. Those in precarious employment are more likely to have such concerns given their temporary employment status and dependence on employers renewing their contracts.

The Employment Precarity Index is used to divide the sample into four employment relationship categories, each representing approximately one-quarter of the total sample. The characteristics of the four categories are described in Table One.

Table 1

Employment Relationship Categories

\begin{tabular}{|l|c|c|c|c|}
\hline & $\begin{array}{c}\text { Average score on } \\
\text { Employment } \\
\text { Precarity Index }\end{array}$ & $\mathbf{n}$ & $\begin{array}{c}\% \\
\text { female }\end{array}$ & $\begin{array}{c}\text { \% } \\
\text { white }\end{array}$ \\
\hline Precarious & 53.5 & 1,008 & 50.5 & 67.1 \\
\hline Vulnerable & 28.1 & 876 & 52.5 & 62.6 \\
\hline Stable & 10.3 & 1,097 & 50.6 & 69.0 \\
\hline Secure & 0.6 & 932 & 55.9 & 75.2 \\
\hline Total Sample & 23.1 & 3913 & 52.1 & 68.5 \\
\hline
\end{tabular}

Source: PEPSO Survey 2011.

Men and women are relatively evenly divided across these four categories, with women and white workers being somewhat over-represented in the Secure category compared to the number of women and white workers in the sample as a whole. 


\section{THE RELATIONSHIP BETWEEN INCOME AND PRECARITY}

Chart One reports the relationship between individual income and the four employment categories. Of those earning less than $\$ 40,000$, half were in Precarious employment and over 80 percent were in either Precarious or Vulnerable employment. For middle income earners earning between $\$ 40,000$ and $\$ 80,000,16$ percent were in Precarious employment and 38 percent were in Precarious or Vulnerable employment. For high income earners earning over \$80,000, 11 percent were in Precarious employment and just under 25 percent were in either Precarious or Vulnerable employment and. Chart One confirms three characteristics of the Toronto-Hamilton labour market. First, those in low wage employment are the most likely to be in Precarious employment. Second, it also indicates that a significant number of workers earning less than $\$ 40,000$ are in relatively stable employment. Third, a significant number of those earning more than $\$ 40,000$ are in relatively insecure employment, particularly those earning between $\$ 40,000$ and $\$ 80,000$.

Chart 1

Employment Insecurity by Individual Income (\%)

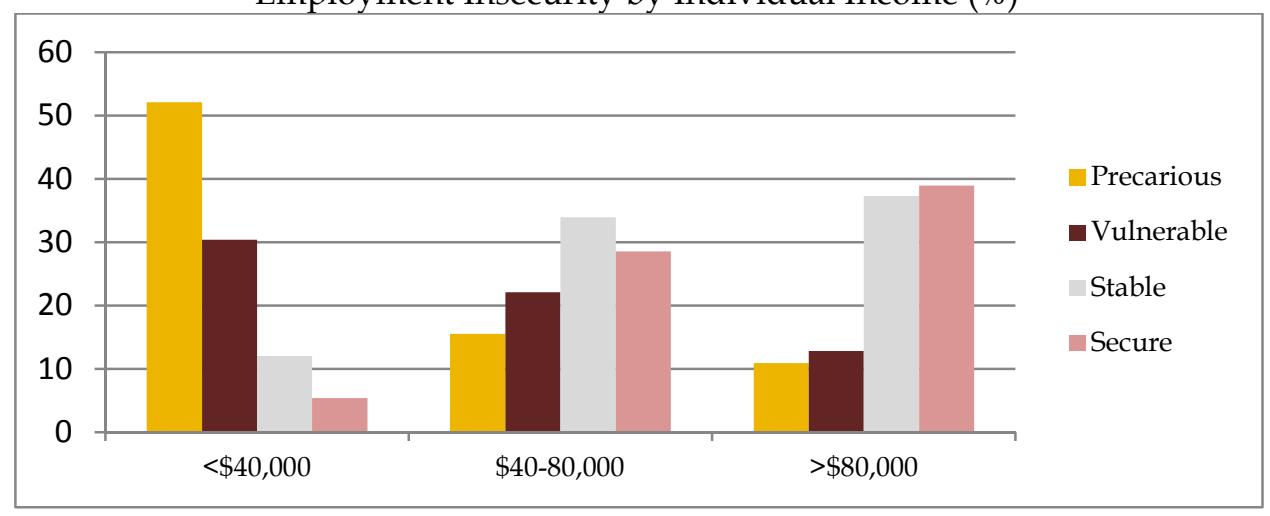

Source: PEPSO Survey 2011.

Respondents were also asked if they received employer funded benefits beyond a basic wage including supplemental health benefits or an employer funded pension plan. The relationship between employment insecurity and receiving additional benefits was strong. Less than ten percent of workers in Precarious employment report receiving supplemental dental, health or vision benefits and only 14 percent report receiving a company pension plan. Over 95 percent of workers in Stable and Secure employment report receiving supplemental benefits and nearly 85 percent receive a company pension plan. 
Chart 2

Supplemental Benefits by Employment Security Levels (\%)

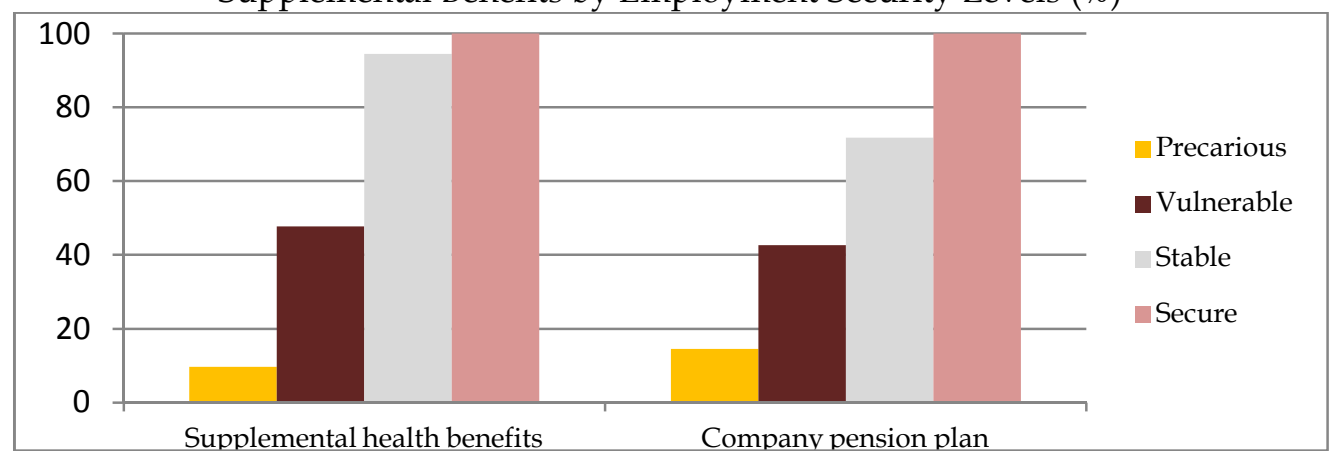

Source: PEPSO Survey 2011.

These findings show that while low income and lack of supplemental employment benefits are correlated with Precarious employment, a substantial number of workers in Precarious employment are in middle or high income brackets. Perhaps the more interesting finding is the number of middle income earners in the Precarious and Vulnerable employment categories. Low income earners represent just under two-thirds of the Precariously employed in our sample, defined as the 25 percent with the highest scores on the Employment Precarity Index. Over 200 workers earning between $\$ 40,000$ and $\$ 80,000$ a year were also Precariously employed and represent about 25 percent of all the Precariously employed in our sample. There were 94 workers earning more than $\$ 80,000$ in Precarious employment representing about 11 percent of all the Precariously employed in our sample.

Table Two uses the components of the Employment Precarity Index to examine the nature of precarious employment at different income levels. Each component was scored out of ten with higher scores indicating greater contributions to the final Index. While there are numerous similarities across the three income categories, there are several differences. Compared to low income Precarious employment, individuals in middle income Precarious employment are significantly less likely to be in jobs with no benefits and less likely not to be paid if they miss work. They are also marginally less likely to be concerned about raising rights at work, less likely to be working on call and less likely to be in a standard employment relationship. Individuals in Precarious employment earning more than $\$ 80,000$ are more likely to be in temporary forms of employment. Over half of this category reported they are own account self-employed compared to less than 20 percent of those earning less than $\$ 40,000$. The high income earners are also less likely not to be paid if they miss work and are the least likely to be reluctant to raise employment rights related to health and safety or employment standards. Individuals in the three income categories are equally likely to report income varying from week to week, the potential for hours of work to be reduced in the next 6 months, not knowing their work schedule in advance and being paid in cash. 
Table 2

Components of the Employment Precarity Index by Income Category for Individuals in Precarious Employment (Scores from 0-10 with 10 most precarious)

\begin{tabular}{|c|c|c|c|}
\hline & $<\$ 40,000$ & $\begin{array}{l}\$ 40,000- \\
\$ 80,000\end{array}$ & $>\$ 80,000$ \\
\hline \multicolumn{4}{|l|}{ Form of employment relationship } \\
\hline Not in a standard employment relationship & 9.91 & $9.71\left(^{*}\right)$ & 9.89 \\
\hline Temporariness of employment & 5.63 & 5.28 & $6.38(* *)$ \\
\hline \multicolumn{4}{|l|}{ Income uncertainty } \\
\hline Income varies from week to week & 5.13 & 5.35 & 4.89 \\
\hline Likely hours will be reduce within 6 months & 3.49 & 3.10 & 3.16 \\
\hline No benefits & 8.91 & $8.34(* *)$ & 8.72 \\
\hline Not paid if miss work & 9.28 & $8.51(* *)$ & $8.62(* *)$ \\
\hline \multicolumn{4}{|l|}{ Scheduling uncertainty } \\
\hline Work on-call & 3.81 & $3.34\left(^{*}\right)$ & 4.10 \\
\hline Don't know work schedule one week in advance & 4.08 & 4.03 & 3.64 \\
\hline \multicolumn{4}{|l|}{ Relationship uncertainty } \\
\hline Paid in cash & 1.52 & 1.33 & 1.33 \\
\hline $\begin{array}{l}\text { Raising H\&S or employment right could affect } \\
\text { employment }\end{array}$ & 3.13 & $2.66\left(^{*}\right)$ & $2.05(* *)$ \\
\hline $\mathrm{n}$ & 538 & 208 & 94 \\
\hline
\end{tabular}

Source: PEPSO Survey 2011 Difference in mean test using $<\$ 40,000$ as the reference. $\left({ }^{*} \mathrm{p}<=.10 ;{ }^{* *} \mathrm{p}<=.05 ;{ }^{* * *} \mathrm{p}<=.001\right)$

\section{GENDER AND THE RELATIONSHIP BETWEEN INCOME AND PRECARITY}

Table Three reports findings by gender on the relationship between income and precarious employment. Women who responded to our survey are paid on average about 13 percent less than men. However, the relationship is reversed on the Employment Precarity Index with men scoring about seven percent higher on average. Both of these findings are statistically significant. The income finding confirms the continued disadvantage women face in the labour market despite their increased participation. This income disadvantage exists despite more women than men reporting their jobs require a university degree. The concentration of women in the service sector likely contributes to their low pay, but does not appear to be shaping overall levels of employment insecurity relative to men. The increase in male precarious employment reflects the downward trend in employment security in the non-service sectors of the economy and in particular in the manufacturing, construction and the primary sectors where men are more prevalent. The Employment Precarity Index finding in Table Three is strong support for the feminization of labour markets hypothesis. 
Table 3

Income and Precarity by Gender

\begin{tabular}{|l|c|c|c|}
\hline & Men & Women & $\begin{array}{c}\text { \% } \\
\text { Difference } \\
\text { Men vs. } \\
\text { Women }\end{array}$ \\
\hline Average individual income (\$) & 64,363 & $55,712\left(^{* * *}\right)$ & 13.4 \\
\hline $\begin{array}{l}\text { Employment Precarity Index (0-100) } 100= \\
\text { high precarity }\end{array}$ & 24.0 & $22.4\left(^{* *}\right)$ & 6.7 \\
\hline Percentage employed in the knowledge sector & 39.5 & 40.9 & -3.5 \\
\hline Percentage employed in the service sector & 35.6 & $51.4\left(^{* * *}\right)$ & -44.4 \\
\hline $\begin{array}{l}\text { Percentage employed in jobs that require a } \\
\text { university degree }\end{array}$ & 45.7 & $47.9\left(^{(*)}\right.$ & -4.8 \\
\hline Average weekly hours & 39.6 & $34.8\left(^{* * *}\right)$ & 12.1 \\
\hline
\end{tabular}

Source: PEPSO Survey 2011 Difference in mean test using male as the reference.

$\left({ }^{*} \mathrm{p}<=.10 ;{ }^{* *} \mathrm{p}<=.05 ;{ }^{* * *} \mathrm{p}<=.001\right)$

\section{COMPONENTS OF PRECARITY BY GENDER}

The finding that men score marginally higher on the Employment Precarity Index than women raises questions whether men and women score similarly on the ten components that make up the Index. Table Four reports the average score for men and for women out of ten on each of the ten components that make up the Index. In all cases, the higher the score on each component, the more this component contributes to defining an employment relationship as precarious.

Women score significantly higher on only one of the ten components, while men score higher on six of the components. There is no significant difference on three components. Men score higher on two of the four indicators of income uncertainty. They report more scheduling uncertainty and more relationship uncertainty.

- About 49 percent of women are not in a standard employment relationship compared to about 45 percent of men.

- Men are more likely to report their income varies from week to week and more likely to report not being paid if they miss work.

- Men are more likely to work on-call or report they do not know their work schedule from week to week.

- Men are more likely to report being paid in cash and are more likely to report that raising a health and safety or employment right might negatively affect their future employment.

- There is no difference between men and women in the temporariness of the employment relationship, a measure that includes whether employment is through a temporary employment agency, or if the employment relationship is casual, short-term, fixed term or ownaccount self-employment. 
- Men and women are equally likely to report their hours might be reduced in the next six months and that they do not receive any benefits beyond a basic wage.

While many of the differences in Table Four are relatively small, even when statistically significant, they do suggest a convergence in overall employment conditions for men and women consistent with the feminization of labour markets thesis. They may also point to a decline in the advantage of being in a "permanent" job. Men are still more likely to be in a form of the employment relationship that resembles a Standard Employment Relationship. However, on average, men are not reporting less income, scheduling, or relationship uncertainty than women. Some of the reported convergence in the terms of employment of men and women reflects gains women have made since the 1970s in demanding more permanent employment. One indication of this is the higher percentage of women in the study reporting they are union members relative to men. Just over 24 percent of the men in the sample are union members compared to over 29 percent of women. This is consistent with the most recent report from Statistics Canada on the terms and conditions of employment of women relative to men (Statistics Canada 2013). Despite the apparent convergence between men and women in our measure of employment precarity, the long standing income gap between women and men has been more challenging to bridge.

Table 4

Components of the Employment Precarity Index by Gender (Scores from 0-10 with 10 most precarious)

\begin{tabular}{|c|c|c|}
\hline & Men & Women \\
\hline \multicolumn{3}{|l|}{ Form of employment relationship } \\
\hline Not in a standard employment relationship & 4.48 & $4.93(* *)$ \\
\hline Temporariness of employment & 1.80 & 1.91 \\
\hline \multicolumn{3}{|l|}{ Income uncertainty } \\
\hline Income varies from week to week & 2.41 & $2.03(* * *)$ \\
\hline Likely hours will be reduce within 6 months & 1.41 & 1.33 \\
\hline No benefits & 3.87 & 4.02 \\
\hline Not paid if miss work & 3.84 & $3.51(* *)$ \\
\hline \multicolumn{3}{|l|}{ Scheduling uncertainty } \\
\hline Work on-call & 1.86 & $1.52(* * *)$ \\
\hline Don't know work schedule one week in advance & 1.89 & $1.35(* * *)$ \\
\hline \multicolumn{3}{|l|}{ Relationship uncertainty } \\
\hline Paid in cash & 0.64 & $0.46(* * *)$ \\
\hline $\begin{array}{l}\text { Raising H\&S or employment right could affect } \\
\text { employment }\end{array}$ & 1.78 & $1.52(* *)$ \\
\hline $\mathrm{n}$ & 1,875 & 2,038 \\
\hline
\end{tabular}

Source: PEPSO Survey 2011 Difference in mean test using male as the reference. $\left({ }^{*} \mathrm{p}<=.10 ;{ }^{* *} \mathrm{p}<=.05 ;{ }^{* * *} \mathrm{p}<=.001\right)$ 
61 Just Labour: A Canadian Journal of Work and Society - Volume 22 - Autumn 2014

\section{THE CHARACTERISTICS OF PRECARIOUS EMPLOYMENT}

The analysis above focused on workers from all four employment precarity categories defined in Table Two. This section focuses only on the experience of men and women in Precarious employment, the 25 percent of the sample with the highest scores on the Employment Precarity Index. ${ }^{2}$ It explores how each gender experiences Precarious employment.

Table Five reports findings by gender for workers in Precarious employment. Within this segment of the workforce, women earned 23 percent less than men, a larger gap than for the sample as a whole. Men score two percent higher than women on the Employment Precarity Index, which represents a narrowing of the gender gap relative to the sample as a whole. Compared to the sample as a whole, women are even more likely to be in service sector jobs than men. They are also still more likely to be in jobs that require a university degree than men. Table Five indicates that women in Precarious employment suffer a significant financial penalty relative to men in Precarious employment. Part of this gap in earnings reflects women in Precarious employment working seven fewer hours per week than men in Precarious employment.

Table 5

Income and Precarity by Gender of Workers in Precarious Employment

\begin{tabular}{|l|c|c|c|}
\hline & Men & Women & $\begin{array}{c}\text { \% } \\
\text { Difference } \\
\text { Men vs } \\
\text { Women }\end{array}$ \\
\hline Average individual income (\$) & 45,248 & $34,881\left(^{* * *}\right)$ & 22.9 \\
\hline $\begin{array}{l}\text { Employment Precarity Index (0-100) 100= } \\
\text { high precarity }\end{array}$ & 54.5 & $53.3(* *)$ & 2.2 \\
\hline $\begin{array}{l}\text { Percentage employed in the knowledge } \\
\text { sector }\end{array}$ & 35.8 & 36.4 & -1.7 \\
\hline Percentage employed in the service sector & 34.9 & $58.0\left(^{* * *}\right)$ & -66.2 \\
\hline $\begin{array}{l}\text { Percentage employed in jobs that require } \\
\text { a university degree }\end{array}$ & 28.7 & $36.0\left(^{* * *}\right)$ & -25.4 \\
\hline Average weekly hours & 34.2 & $26.9\left(^{* * *}\right)$ & 7.3 \\
\hline
\end{tabular}

Note: This table reports findings for the 25 percent of the sample with the highest scores on the Employment Precarity Index. Source: PEPSO Survey 2011 Difference in mean test using male as the reference. $\left({ }^{*} \mathrm{p}<=.10 ;{ }^{* *} \mathrm{p}<=.05 ;{ }^{* * *} \mathrm{p}<=.001\right)$

Table Six reports how men and women in Precarious employment score on the ten components that make up the Employment Precarity Index. Women score higher than men on two of the ten indicators and men score higher than women on three.

- The overwhelming majority of workers in Precarious employment are not in a standard employment relationship. Women are marginally more likely than men to not be in a standard employment relationship.

- Men are more likely to report not knowing their schedule in advance. 
- Men are more likely to report relationship uncertainty reflected in being more likely to be paid in cash and more likely to be concerned that trying to enforce their rights at work might affect future employment.

- There is convergence on the income uncertainty components compared to the sample as a whole. Women are more likely than men to report not being paid if they miss work.

Just over 16 percent of the men in Precarious employment were union members compared to 20 percent of women.

Table 6

Components of the Employment Precarity Index

by Gender of Workers in Precarious Employment

(Scores from 0-10 with 10 most precarious)

\begin{tabular}{|c|c|c|}
\hline & Men & Women \\
\hline \multicolumn{3}{|l|}{ Form of employment relationship } \\
\hline Not in a standard employment relationship & 9.78 & $9.93(* * *)$ \\
\hline Temporariness of employment & 5.55 & 5.70 \\
\hline \multicolumn{3}{|l|}{ Income uncertainty } \\
\hline Income varies from week to week & 5.33 & $5.00\left(^{*}\right)$ \\
\hline Likely hours will be reduce within 6 months & 3.30 & 3.41 \\
\hline No benefits & 8.82 & 8.82 \\
\hline Not paid if miss work & 8.82 & $\left.9.19{ }^{(* *}\right)$ \\
\hline \multicolumn{3}{|l|}{ Scheduling uncertainty } \\
\hline Work on-call & 3.87 & 3.59 \\
\hline Don't know work schedule one week in advance & 4.36 & $3.70(* * *)$ \\
\hline \multicolumn{3}{|l|}{ Relationship uncertainty } \\
\hline Paid in cash & 1.62 & $1.30(* *)$ \\
\hline $\begin{array}{l}\text { Raising H\&S or employment right could affect } \\
\text { employment }\end{array}$ & 3.18 & $2.62(* *)$ \\
\hline
\end{tabular}

Note: This table reports findings for the 25 percent of the sample with the highest scores on the Employment Precarity Index. Source: PEPSO Survey 2011 Difference in mean test using male as the reference. $\left({ }^{*} \mathrm{p}<=.10\right.$; ${ }^{* *} \mathrm{p}<=.05$; ${ }^{* * *}$ $\mathrm{p}<=.001)$

Tables Seven and Eight repeat the exercise above but for men and women in the middle ranges of the Employment Precarity Index, those in Vulnerable or in Stable employment. ${ }^{3}$ This group experiences moderate employment stability. The income gap between men and women was 13 percent, somewhat less than the gap between men and women in Precarious employment relationships but about the same as the sample as a whole. Women in these middle ranges work about four hours less per week than men. Men scored about 3 percent higher than women on the Employment Precarity Index which was marginally higher than those in Precarious employment and about the same as in the sample as a whole. This difference in employment insecurity between men and women was only marginally statistically significant suggesting a wider variance in the Index for workers in moderate employment 
stability. Women continue to be more likely to be employed in the service sector, but not by as wide a margin as was the case for women in Precarious employment.

\section{Table 7}

Income and Precarity by Gender of Workers in Middle Ranges of the Employment Precarity Index

\begin{tabular}{|l|c|c|c|}
\hline & Men & Women & $\begin{array}{c}\text { \% Difference } \\
\text { Men vs } \\
\text { Women }\end{array}$ \\
\hline Average individual income (\$) & 66,709 & $57,805\left(^{* * *}\right)$ & 13.3 \\
\hline $\begin{array}{l}\text { Employment Precarity Index (0-100) 100 } \\
\text { high precarity }\end{array}$ & 18.5 & $17.9\left(^{*}\right)$ & 3.2 \\
\hline $\begin{array}{l}\text { Percentage employed in the knowledge } \\
\text { sector }\end{array}$ & 37.2 & 39.1 & -5.1 \\
\hline $\begin{array}{l}\text { Percentage employed in the service } \\
\text { sector }\end{array}$ & 35.1 & $50.8\left(^{* * *}\right)$ & -44.7 \\
\hline $\begin{array}{l}\text { Percentage employed in jobs that } \\
\text { require a university degree }\end{array}$ & 46.2 & 46.0 & 0.0 \\
\hline Average weekly hours & 41.5 & $37.1\left(^{* * *}\right)$ & 10.6 \\
\hline
\end{tabular}

Note: This table reports findings for the half of the sample who scored in the middle two quartiles on the Employment Precarity Index. Source: PEPSO Survey 2011

Difference in mean test using male as the reference. $\left({ }^{*} \mathrm{p}<=.10 ;{ }^{* *} \mathrm{p}<=.05 ;{ }^{* * *} \mathrm{p}<=.001\right)$

Table Eight reports how men and women in moderate employment stability score on the ten components that make up the Employment Precarity Index. Women scored higher than men on three of the ten components of the index while men scored higher on five of the ten.

- Almost half of all women in these middle categories were not in a standard employment relationship compared to about one-third of men. The employment women worked at was also more temporary. This represents a major difference from the sample as a whole and from the findings for those in Precarious employment.

- Women are more likely than men to be employed in jobs that do not pay any benefits.

- Men continue to be more likely to report their income varies from week to week and that they are not paid if they miss work.

- Men report greater scheduling uncertainty on both of the measures in this section. They are more likely to be paid in cash but as likely to report raising a health and safety or employment right might affect future employment.

- Women continue to be slightly more likely to be union members in this range, 29 percent, compared to men at 26 percent. 
Table 8

Components of the Employment Precarity Index by

Gender of Workers in the Middle Ranges of the Employment Precarity Index

(Scores from 0-10 with 10 most precarious)

\begin{tabular}{|c|c|c|}
\hline & Men & Women \\
\hline \multicolumn{3}{|c|}{ Components of precarity index (0-10 with 10 in precarious) } \\
\hline \multicolumn{3}{|l|}{ Form of employment relationship } \\
\hline Not in a standard employment relationship & 3.69 & $4.89(* * *)$ \\
\hline Temporariness of employment & 0.67 & $0.88(* *)$ \\
\hline \multicolumn{3}{|l|}{ Income uncertainty } \\
\hline Income varies from week to week & 1.82 & $1.38(* * *)$ \\
\hline Likely hours will be reduce within 6 months & 1.05 & 0.93 \\
\hline No benefits & 3.08 & $3.58(* *)$ \\
\hline Not paid if miss work & 2.96 & $2.34(* * *)$ \\
\hline \multicolumn{3}{|l|}{ Scheduling uncertainty } \\
\hline Work on-call & 1.54 & $1.14(* * *)$ \\
\hline Don't know work schedule one week in advance & 1.41 & $0.72(* * *)$ \\
\hline \multicolumn{3}{|l|}{ Relationship uncertainty } \\
\hline Paid in cash & 0.41 & $0.26(* * *)$ \\
\hline $\begin{array}{l}\text { Raising H\&S or employment right could affect } \\
\text { employment }\end{array}$ & 1.82 & 1.74 \\
\hline
\end{tabular}

Note: This table reports findings for the half of the sample who scored in the middle two quartiles on the Employment Precarity Index. Source: PEPSO Survey 2011 Difference in mean test using male as the reference. $\left({ }^{*} \mathrm{p}<=.10\right.$; ${ }^{*}$ $\left.\mathrm{p}<=.05 ;{ }^{* * *} \mathrm{p}<=.001\right)$

Exploring the terms and conditions of employment by gender and by degree of employment security suggests that the findings for the sample as a whole do not fully reflect the findings for men and women either in Precarious employment or men and women in Vulnerable and Stable employment. Women in Precarious employment, the quarter of our sample with the highest scores on the Employment Relationship Index, experience an even larger income gap than men relative to our sample as a whole. They also lose most of the small advantage they had over men on the Employment Precarity Index. In Vulnerable and Stable employment, the income gap between men and women is narrower than for those in Precarious employment and women report a small, but statistically weak, advantage over men on the Employment Precarity Index. Women in the middle ranges are much more likely than men not to be in a standard employment relationship and more likely to be in temporary employment.

\section{RACIALIZATION AND THE RELATIONSHIP BETWEEN INCOME AND PRECARITY}

Table Nine reports findings on the relationship between low income and employment precarity by race. ${ }^{4}$ White workers are paid 16 percent more than nonwhite workers but both groups work about the same number of hours. On the Employment Precarity Index, white workers score about 11 percent lower than nonwhite workers. White workers are more likely to be working in the knowledge 
sector and are about 5 percent more likely to require a university degree compared to non-white workers.

Table 9

Income and Precarity by Race

\begin{tabular}{|l|c|c|c|}
\hline & White & Non-white & $\begin{array}{c}\% \\
\text { Difference } \\
\text { White vs } \\
\text { Non-white }\end{array}$ \\
\hline Average individual income (\$) & 63,321 & $\left.52,8933^{* * *}\right)$ & 16.5 \\
\hline $\begin{array}{l}\text { Employment Precarity Index (0-100) 100= } \\
\text { high precarity }\end{array}$ & 22.5 & $25.0\left(^{* * *}\right)$ & -11.1 \\
\hline $\begin{array}{l}\text { Percentage employed in the knowledge } \\
\text { sector }\end{array}$ & 41.9 & $35.4\left(^{* * *}\right)$ & 15.5 \\
\hline Percentage employed in the service sector & 43.3 & 45.4 & -4.8 \\
\hline $\begin{array}{l}\text { Percentage employed in jobs that require a } \\
\text { university degree }\end{array}$ & 47.9 & $43.4\left(^{* *}\right)$ & 9.4 \\
\hline Average weekly hours & 37.0 & 36.9 & 0.0 \\
\hline
\end{tabular}

Source: PEPSO Survey 2011 Difference in mean test using white as the reference.

$\left({ }^{*} \mathrm{p}<=.10 ;{ }^{* *} \mathrm{p}<=.05 ;{ }^{* * *} \mathrm{p}<=.001\right)$

\section{COMPONENTS OF PRECARITY BY RACE 5}

Table Ten reports how white and non-white workers score on the ten components that make up the Employment Precarity Index. Non-white workers score higher than whites on four of the ten components of the index, including two of the four indicators of income uncertainty, and on the measure of reluctance to raise health and safety and employment rights. Non-white workers are less likely to be employed in a standard employment relationship but overall they report similar levels of temporariness of their employment relationship. The latter is a measure of the prevalence of short-term contract employment, temporary agency employment and own-account self employment.

The finding that white and non-white workers have similar scores on the measure of employment temporariness, a measure based on the form of the employment relationship, suggests that non-white workers still find themselves employed under different terms and conditions than white workers given the form of the employment relationship. They report more income uncertainty and more relationship uncertainty reflected in the higher scores on not being paid if you miss work, concern that their hours of work will be reduced in the near future and not being able to assert employment rights at work. 
Table 10

Components of Employment Precarity Index by Race (Scores from 0-10 with 10 most precarious)

\begin{tabular}{|l|c|c|}
\hline \multicolumn{2}{|l|}{ White } & Non-white \\
\hline Form of employment relationship & 4.60 & $4.98\left(^{* *}\right)$ \\
\hline Not in a standard employment relationship & 1.85 & 1.85 \\
\hline Temporariness of employment & 2.20 & 2.27 \\
\hline Income uncertainty & 1.21 & $1.69\left(^{* * *}\right)$ \\
\hline Income varies from week to week & 3.92 & 4.02 \\
\hline Likely hours will be reduce within 6 months & 3.56 & $3.94\left(^{* *}\right)$ \\
\hline No benefits & 1.68 & 1.70 \\
\hline Not paid if miss work & 1.59 & 1.67 \\
\hline Scheduling uncertainty & 0.52 & 0.63 \\
\hline Work on-call & 1.35 & $2.26\left(^{* * *}\right)$ \\
\hline Don't know work schedule one week in advance & \\
\hline Relationship uncertainty & \multicolumn{2}{|l|}{} \\
\hline Paid in cash & \multicolumn{1}{|l|}{} \\
\hline $\begin{array}{l}\text { Raising H\&S or employment right could affect } \\
\text { employment }\end{array}$ &
\end{tabular}

Source: PEPSO Survey 2011 Difference in mean test using white as the reference.

$\left({ }^{*} \mathrm{p}<=.10 ;{ }^{* *} \mathrm{p}<=.05 ;{ }^{* * *} \mathrm{p}<=.001\right)$

Tables Eleven and Twelve examine how white and non-white workers in Precarious employment experience precarity. They focus on the quarter of the sample with the highest scores on the Employment Precarity Index. Table Eleven indicates that white workers earn more on average and score higher on the Index, but that neither of these findings is statistically significant at the 5 percent level. This is despite significant differences in the percentage of white workers in the knowledge sector and the percentage requiring a university degree to perform their jobs.

Table 11

Income and Precarity by Race of Workers in Precarious Employment

\begin{tabular}{|l|c|c|c|}
\hline & White & Non-white & $\begin{array}{c}\text { \% Difference } \\
\text { White vs Non- } \\
\text { white }\end{array}$ \\
\hline Average individual income (\$) & 40,506 & 39,097 & 3.5 \\
\hline $\begin{array}{l}\text { Employment Precarity Index (0-100) } 100= \\
\text { high precarity }\end{array}$ & 54.32 & $53.19\left(^{*}\right)$ & 2.1 \\
\hline $\begin{array}{l}\text { Percentage employed in the knowledge } \\
\text { sector }\end{array}$ & 37.8 & $31.0(* *)$ & 18.0 \\
\hline Percentage employed in the service sector & 48.4 & 44.7 & 7.6 \\
\hline $\begin{array}{l}\text { Percentage employed in jobs that require a } \\
\text { university degree }\end{array}$ & 33.9 & $28.3(* *)$ & 16.5 \\
\hline Average weekly hours & 29.3 & 31.4 & -7.2 \\
\hline
\end{tabular}

Note: This table reports findings for the 25 percent of the sample with the highest scores on the Employment Precarity Index. Source: PEPSO Survey 2011 Difference in mean test using white as the reference. $\left({ }^{*} \mathrm{p}<=.10 ;{ }^{* *} \mathrm{p}<=.05 ;{ }^{* * *} \mathrm{p}<=.001\right)$ 
Table Twelve reports how white and non-white workers in Precarious employment score on the ten components that make up the Employment Precarity Index. The findings suggest that white and non-white workers experience precarity somewhat differently. While there is only a small difference in the average Index score of white and non-white workers reported in Table Eleven, there are several significant differences on the individual components that make up the index. Whites are more likely to report not being in a standard employment relationship. They are less likely to be in jobs with benefits, more likely to report not being paid if they miss work, and more likely to report their income varies from week to week. Non-white workers are more likely to report reluctance to assert health and safety and employment rights at work.

How might we understand the generally higher scores of whites in Precarious employment on many of the components that make up the Index compared nonwhite workers? Much of this difference likely reflects the different distribution of white and non-white workers across several of the different forms of the employment relationship. Just over 8 percent of white workers receive half their income from temporary employment agency work, compared to over 19 percent of non-white workers. However, over 32 percent of white workers in Precarious employment are own-account self-employed compared to just under 20 percent of non-white workers. It appears that for white workers in Precarious employment, own-account self-employment is even more insecure than employment through a temporary employment agency.

Table 12

Components of the Employment Precarity Index

by Race of Workers in Precarious Employment

(Scores from 0-10 with 10 most precarious)

\begin{tabular}{|c|c|c|}
\hline & White & Non-white \\
\hline \multicolumn{3}{|l|}{ Form of employment relationship } \\
\hline Not in a standard employment relationship & 9.94 & $9.69(* *)$ \\
\hline Temporariness of employment & 5.69 & 5.49 \\
\hline \multicolumn{3}{|l|}{ Income uncertainty } \\
\hline Income varies from week to week & 5.62 & $4.37(* * *)$ \\
\hline Likely hours will be reduce within 6 months & 3.15 & $3.75(* *)$ \\
\hline No benefits & 8.97 & $8.33(* * *)$ \\
\hline Not paid if miss work & 9.20 & $8.72(* *)$ \\
\hline \multicolumn{3}{|l|}{ Scheduling uncertainty } \\
\hline Work on-call & 3.77 & 3.67 \\
\hline Don't know work schedule one week in advance & 4.00 & 4.04 \\
\hline \multicolumn{3}{|l|}{ Relationship uncertainty } \\
\hline Paid in cash & 1.45 & 1.51 \\
\hline $\begin{array}{l}\text { Raising H\&S or employment right could affect } \\
\text { employment }\end{array}$ & 2.51 & $3.63(* * *)$ \\
\hline
\end{tabular}

Note: This table reports findings for the 25 percent of the sample with the highest scores on the Employment Precarity Index. Source: PEPSO Survey 2011 Difference in mean test using white as the reference. $\left({ }^{*} \mathrm{p}<=.10 ;{ }^{* *} \mathrm{p}<=.05 ;{ }^{* * *} \mathrm{p}<=.001\right)$ 
Table Thirteen reports average income and Index scores of white and non-white workers in Vulnerable and Stable employment. In these middle ranges, non-white racialized workers are paid significantly less and score higher on the Employment Precarity Index. There is no difference in the average hours worked per week, the percentage working in the service sector, or the percentage in jobs requiring a university degree. White workers are more likely to be in jobs requiring a university degree.

Table 13

Income and Precarity by Race of Workers in Middle Ranges of the Employment Precarity Index

\begin{tabular}{|l|c|c|c|}
\hline & White & Non-white & $\begin{array}{c}\% \\
\text { Difference } \\
\text { White vs Non- } \\
\text { white }\end{array}$ \\
\hline Average individual income (\$) & 66,313 & $54,794\left(^{* * *}\right)$ & 17.4 \\
\hline $\begin{array}{l}\text { Employment Precarity Index (0-100) } 100=\text { high } \\
\text { precarity }\end{array}$ & 17.76 & $18.95\left(^{* *}\right)$ & -6.7 \\
\hline Percentage employed in the knowledge sector & 40.1 & $34.1\left(^{* *}\right)$ & 15.0 \\
\hline Percentage employed in the service sector & 41.9 & 44.9 & -7.2 \\
\hline $\begin{array}{l}\text { Percentage employed in jobs that require a } \\
\text { university degree }\end{array}$ & 47.0 & $43.4\left(^{*}\right)$ & 7.7 \\
\hline Average weekly hours & 39.2 & 38.8 & 1.0 \\
\hline
\end{tabular}

Note: This table reports findings for the half of the sample who scored in the middle two quartiles on the Employment Precarity Index. Source: PEPSO Survey 2011 Difference in mean test using white as the reference. $\left({ }^{*} \mathrm{p}<=.10 ;{ }^{* *} \mathrm{p}<=.05 ;{ }^{* * *} \mathrm{p}<=.001\right)$

Table 14

Components of the Employment Precarity Index by Race of Workers in the Middle Ranges of the Employment Precarity Index (Scores from 0-10 with 10 most precarious)

\begin{tabular}{|c|c|c|}
\hline & White & Non-white \\
\hline \multicolumn{3}{|l|}{ Form of employment relationship } \\
\hline Not in a standard employment relationship & 4.31 & 4.27 \\
\hline Temporariness of employment & 0.86 & $0.63(* *)$ \\
\hline \multicolumn{3}{|l|}{ Income uncertainty } \\
\hline Income varies from week to week & 1.45 & $1.88(* * *)$ \\
\hline Likely hours will be reduce within 6 months & 0.86 & $1.21(* *)$ \\
\hline No benefits & 3.43 & 3.18 \\
\hline Not paid if miss work & 2.55 & 2.85 \\
\hline \multicolumn{3}{|l|}{ Scheduling uncertainty } \\
\hline Work on-call & 1.39 & 1.22 \\
\hline Don't know work schedule one week in advance & 1.12 & 0.99 \\
\hline \multicolumn{3}{|l|}{ Relationship uncertainty } \\
\hline Paid in cash & 0.31 & 0.40 \\
\hline Raising H\&S or employment right could affect employment & 1.49 & $2.32(* * *)$ \\
\hline
\end{tabular}

Note: This table reports findings for the half of the sample who scored in the middle two quartiles on the Employment Precarity Index. Source: PEPSO Survey 2011 Difference in mean test using white as the reference. $\left({ }^{*} \mathrm{p}<=.10 ;{ }^{* *} \mathrm{p}<=.05 ;{ }^{* * *} \mathrm{p}<=.001\right)$ 
Table Fourteen reports how white and non-white workers in Vulnerable and Stable employment score on the ten components that make up the Employment Precarity Index. White workers report higher scores on only one component of the Index while non-white workers score higher on three of the ten components. This is a significant difference from the experience of white and non-white workers in Precarious employment where white workers tended to score higher on several of the components of the Index. For workers in Vulnerable and Stable employment, white workers are in more temporary relationships. Non-white workers are more likely to report income varies from week to week, that their hours will be reduced in the next 6 months, and reluctance to raise health and safety or employment rights issues at work.

\section{DISCUSSION}

This paper set out to explore two questions: what is the relationship between employment insecurity and income levels, and does this relationship vary by gender and race. The findings suggest a complex relationship between income and employment precarity. Low income does translate into a higher probability that a worker will score higher on the Employment Precarity Index. However a significant number of low income workers are not in precarious employment, the 25 percent of our sample with the highest scores on the Employment Precarity Index. As well, a significant number of workers in Precarious employment are not low income. Over one-third of all the workers who we identify as precariously employed earn $\$ 40,000$ or more. They represent not only a significant component of the precariously employed, but likely a growing component as more employers abandon the Standard Employment Relationship and opt for less secure forms of employment.

Comparing the experiences of men and women reveals that while women continue to be paid less than men, they do not occupy less secure jobs as measured by the Employment Precarity Index. The earnings disadvantage of women is especially large for women in Precarious employment relative to men in Precarious employment. The income disadvantage narrows, but does not disappear for women in Vulnerable and Stable employment. These findings support the feminization of labour markets thesis with the important nuance that while men appear to be employed in relationships that are as insecure as women, men retain a significant income advantage over women.

Racialization continues to shape both the income and the employment insecurity characteristics of white and non-white workers. In the sample as a whole, white workers earn more on average and report less employment insecurity. However, for those in Precarious employment, there are no statistically significant differences in either average income or the average Employment Insecurity Index measure between white and non-white workers. When we examined the components of the Employment Precarity Index, white workers in Precarious employment report more income insecurity while non-white workers reported 
more relationship uncertainty. We argue that this may be explained by the prevalence of own-account self-employment amongst white workers in Precarious employment. However, for workers in moderately secure employment there were still significant differences in the Index by race. Non-white workers earned less and reported less secure employment. They reported more income uncertainty and more relationship uncertainty.

A detailed review of how men and women scored on the ten components of the Employment Precarity Index revealed an interesting pattern. While men tended to be more likely to be in a Standard Employment Relationship and in employment that was less temporary, they scored higher on many of the direct measures of employment insecurity. Men scored higher on indicators of income insecurity, scheduling uncertainty and relationship uncertainty. This was true for the sample as a whole, amongst those in Precarious employment and amongst those in moderately secure employment. This finding suggests that simply focusing on indirect measures of employment insecurity such as the form of the employment relationship may not fully reflect the underlying insecurity associated with uncertain earnings, loss of control over work schedules and relationship uncertainty.

This paper provides evidence that there has been a convergence between men and women in the degree of employment insecurity inherent in their jobs. It also confirms that there continues to be a significant racialized impact on both earnings and employment security to the disadvantage of non-white workers. These results suggest that while men have been partially successful in maintaining an earnings advantage over women, in part through working more hours than women, they have not been able to shield themselves from the uncertainty associated with precarious employment. The process of feminizing labour markets is only partial as men continue to earn more than women.

The implications of these findings require researchers to assess changes in the nature of the Standard Employment Relationship that appears to be becoming less prevalent, but also less secure. Many of our social relationships, including how unions represent workers, how households shield themselves from economic uncertainty, and how individuals engage their community have all been structured around an earlier model of the Standard Employment Relationship which appears to have been more secure than the current version. How the increasing prevalence of insecure employment and the declining security of the Standard Employment Relationship are affecting social relations is a subject for future research.

\section{APPENDIX ONE: DATA SOURCES}

PEPSO commissioned Leger Marketing to conduct a telephone survey in the fall of 2011 via random digit dialing. Leger was provided with a fixed response survey by the research team. The sample is representative by age, gender and broad geographical areas within the GTA-Hamilton labour market. Workers were between the ages of 25 and 65 and had to have worked for pay at sometime in the 3 
months prior to the survey. A total of 4,165 qualified respondents completed the survey. In this paper we examine the responses from the 4,019 non-employers in the survey. The survey was conducted in English and its average length was 15 minutes. ${ }^{6}$

Table A

One Sample Characteristics

\begin{tabular}{|l|l|}
\hline \multicolumn{2}{|c|}{ Age } \\
\hline $25-34$ & $1,017(25.3 \%)$ \\
\hline $35-44$ & $1,194(29.7 \%)$ \\
\hline $45-54$ & $1,066(26.5 \%)$ \\
\hline $55-64$ & $741(18.4 \%)$ \\
\hline \multicolumn{2}{|c|}{ Gender } \\
\hline Male Race \\
\hline Female & $1,927(48.0 \%)$ \\
\hline \multicolumn{2}{|c|}{$2,091(52.0 \%)$} \\
\hline White & $2,695(68.5 \%)$ \\
\hline Chinese $149(3.8 \%)$ \\
\hline Other non-white & $1,089(27.7 \%)$ \\
\hline \multicolumn{2}{|c|}{ Individual Income } \\
\hline$<\$ 40,000$ & $1,054(32.2 \%)$ \\
\hline$\$ 40,00-79,999$ & $1,363(41.5 \%)$ \\
\hline$>=\$ 80,000$ & $861(26.3 \%)$ \\
\hline
\end{tabular}

Unless indicated otherwise, all figures in this paper were drawn from the PEPSO 2011 data base.

\section{NOTES}

1 Details of how this was done are available from the authors. See Goldring and Landolt $(2009,2011)$ for another example of an Index of Precarious Employment.

2 Those in Precarious employment scored between 40 and 95 on the Employment Precarity Index.

3 This group scored between 5 and 37.5 on the Employment Precarity Index.

4 We limit the analysis to white and non-white. Further research will look in more detail on how different racialized groups experience precarity.

5 See Goldring and Joly in this volume for a further analysis of racialization, citizenship and legal status, and employment precarity.

6 The sample had a substantial under-representation of ethnic Chinese participants who represented 4.7 percent of the Toronto sample but made up 11.4 percent of the Toronto population in 2006. Efforts were made to conduct the survey in Chinese by a native Chinese speaker. These were unsuccessful. Leger noted the general challenge of accessing individual from Chinese backgrounds via phone surveys. 


\section{ACKNOWLEDGMENTS}

This paper was made possible by the support of funds from the United Way Toronto- McMaster University SSHRC CURA project on Poverty and Employment Precarity in Southern Ontario. Additional financial support was provided by McMaster University and United Way Toronto. We benefitted from feedback by two anonymous journal reviewers. The authors alone are responsible for any shortcomings.

\section{REFERENCES}

Armstrong, Pat. 1996. "The Feminization of the Workforce: Harmonizing Down in a Global Econom." Pp. 29-54 in Rethinking Restructuring: Gender and Change in Canada, edited by Isabella Bakker. Toronto: University of Toronto Press.

Galbauzi, Grace-Edward. 2004. "Racializing the Division of Labour: Neoliberal Restructuring and the Economic Segregation of Canada's Racialized Groups." Pp. 175-204 in Challenging the Market: The Struggle to Regulate Work and Income, edited by Jim Stanford and Leah Vosko. Montreal: McGill-Queen's University Press.

Goldring, Luin and Patricia Landolt. 2011. "Caught in the Work-Citizenship Matrix: The lasting effects of precarious legal status on work for Toronto immigrants." Globalizations 8(3): 325-341.

Goldring, Luin and Patricia Landolt. 2009. Immigrants and Precarious Employment in the New Economy Project, Brief 1: The Index of Precarious work (IPW): A Measure to Track Progress Towards Decent Work. Toronto: York University. Retrieved 16 July 2014

http://www.arts.yorku.ca/research/ine/research/publications.html

Hatton, Erin. 2011. The Temp Economy: From Kelly Girls to Permatemps in Postwar America. Philadelphia: Temple University Press.

Hebson, Gail \& Irena Grugulis. 2005. “Gender and New Organizational Forms." Pp. 217-237 in Fragmenting Work: Blurring Organizational Boundaries and Disordering Hierarchies, edited by Mick Marchington, Damian Grimshaw, Jill Ribery and Hugh Willmott, Oxford: Oxford University Press.

Institute for Competitiveness and Prosperity. 2013. Untapped potential: Creating a better future for service workers (Working Paper 17). Toronto: The Institute for Competitiveness and Prosperity.

Law Commission of Ontario. 2012. Vulnerable Workers and Precarious Work. Toronto.

Lewchuk, Wayne, Marlea Clarke and Alice de Wolff. 2011. Working Without Commitments: Precarious Employment and Health. Montreal: McGill Queen's University Press.

PEPSO. 2013. It's More than Poverty: Employment Precarity and Household Wellbeing. Retrieved 16 July 2014 http:/ / pepso.ca/media/ 
73 Just Labour: A Canadian Journal of Work and Society - Volume 22 - Autumn 2014

Statistics Canada. 2012. Women in Canada: A Gender-based Statistical Report, catalogue number 89-503-XPE. Retrieved 16 July 2014 http:// www5.statcan.gc.ca/bsolc/olc-cel/olc-cel?catno=89-503-XPE\&lang=eng.

TD Economics. 2013. Jobs in Canada, Where, What and For Whom? Retrieved 16 July 2014 http:// www.td.com/document/PDF/economics/special/JobsInCanada.pdf

Vosko, Leah. 2000. Temporary Work: The Gendered Rise of a Precarious Employment Relationship. Toronto: University of Toronto Press.

Vosko, Leah, Matha MacDonald, Iain Campbell. Eds. 2009. Gender and the Contours of Precarious Employment. London: Routledge. 